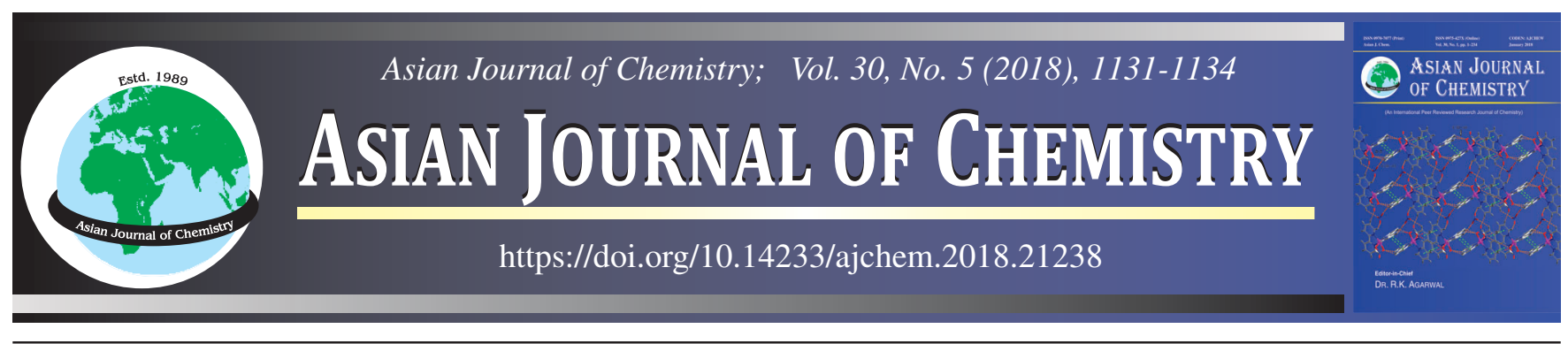

\title{
Characterization of Biodiesel Derived from Crude Oil of Pongamia sps. Grown in Tumkur District, India
}

\section{G. Panduranga Murthy ${ }^{1, *}$ and Rajesh $\operatorname{Kumar}^{2}$}

${ }^{1}$ Maharaja Institute of Technology, Thandavapura, Nanjanagud Tq., Mysuru Dist.-571 302, India

${ }^{2}$ University Department of Chemistry, Ranchi University, Ranchi-834 001, India

*Corresponding author: E-mail: pandu_murthy@ rediffmail.com

Pongamia is non-edible oil which contains several toxic and unsaponifiable components. The presence of these multifarious compositions makes the oil unsuitable for human consumption. However, Pongamia has high oil content ( 40\%) and can grow on malnourished soils with low levels of nitrogen and high levels of salt, which prompts in becoming the focus of a number of biodiesel research programs.

Generally, the oil is contaminated with high free fatty acids (FFAs) depending upon the moisture content in the seed during collection as well as oil expression. In addition, several advantages of Pongamia over other food crops are higher recovery and quality of oil than other crops. As a legume, it is also able to fix its own nitrogen from the soil and atmosphere minimising the need for added fertilisers. Interestingly, Pongamia tree with characteristic seeds containing promising oils and fatty acids suitable for biodiesel production. However, keeping these value-added points, in the current study, the base line survey was under taken to assess the pongamia cultivation in the study area The seeds were collected from the village farmers during interaction and separated the seeds from pods using a suitable decorticator. Then, the seeds were subjected for oil extraction with a specific prototype of oil expeller and characterized physico-chemically. Further, the crude oil was subjected for transesterification using methanol and $\mathrm{NaOH}$ as a catalyst. The reaction mixture was varied in trials with respect to variable time and temperature. Ultimately, the conversion from oil to ester was found to be significant and the yield of biodiesel from high free fatty acid Karanja oil by this approach has been observed to be 96.6-97.8\%. The optimized production was achieved about $97.8 \%$ using a $4.8: 1$ molar ratio of oil with methanol at $90^{\circ} \mathrm{C}$. Later, the obtained esterified oil (biodiesel) was subjected for physicochemical characterization and compared with ASTM biodiesel standards. In conclusion, the pongamia esterified oil found to be most significant with respect to its optimized biodiesel production which can be recommended for the boosting of lively hood of rural farmers through value addition followed by the promising future of fuel industry.

Keywords: Pongamia glabra (Pongamia pinnata L.), Transesterification, Biodiesel, Tumkur.

L

\section{INTRODUCTION}

The methyl or ethyl esters of fatty acid are derived from the both edible and non-edible vegetable oils followed by animal fats which are termed as biodiesel. The chief sources for obtaining biodiesel particularly in India are categorized as non-edible oils of plant species such as Pongamia sps., Jatropha curcas (Ratanjyot), Calophyllum inophyllum (Nag-champa) followed by rubber yielding tree called Hevea brasiliensis, respectively. The biodiesel basically comprising of no petroleum constituents, even though it can be subjected for blending with petroleum diesel at any level to produce variable blends of biodiesel with petroleum diesel or in some instance, the biodiesel can be used in its pure form to serve the purpose [1-4].

There is a significant reduction of unburnt hydrocarbons like carbon monoxide, particulate matters followed by nitrogen oxide in the existing internal combustion engine system fuelled with biodiesel of individual or blending applications. However, the biodiesel has been given an exclusive consideration for solid claim based on the properties such as clean fuel, no aromatics, no sulphur content and it also has 10-12\% built in oxygen which facilitate complete combustion.

The international prices of crude oil are constantly escalating besides depletion in fossil reserves. Hence there is urgent need to search for alternate energies like biofuel. Country's demand for diesel and petrol is in the ratio of 5:1. Ethanol from sugar industry is being used to blend with petrol. But biodiesel production is still in infant stage. The various plant species identified for biodiesel extraction in Karnataka state are pongamia, neem, Jatropa, simaruba, hippe, etc. [5-8].

In recent scenario, the energy stipulation report says that $3.5 \%$ of the commercial energy demand where, India titled in as sixth position. Whereas, the energy claim was anticipated to grow-up at $4.8 \%$ consequently, the demand of petro-diesel 
is proposed to rise from 40.21 million metric tons (during 20012002 ) to 53.32 million metric tons in 2006-2007 resulting in increase in demand @ $5.6 \%$ per annum. India is importing about 150 million tons of crude oil annually accounting to 70$75 \%$ of national requirement. Karnataka state has good potential for biodiesel production [9-11].

Pongamia (Millettia pinnata) belongs to the family, Fabaceae and commonly called 'Indian beech' which is also a native to India apart from other countries such as Malaysia, Indonesia, Taiwan, Bangladesh, Sri Lanka and Myanmar. It is hardy and temperatures from 5 to $50{ }^{\circ} \mathrm{C}$ was recorded and the survival of pongamia in the altitudes ranging from 0 to $1200 \mathrm{~m}$ was observed. Besides, the deep roots of pongamia were found to be most tolerant even for drought at Pavagada taluk, where the inadequate rainfall (200 to $2500 \mathrm{~mm}$ ) in a year was documented. In spite of all the unfavourable conditions, it was noticed that Karanja tree grown well in both full sun and partial shade and can grow up in most soil types without any valuable inputs. In the surveyed regions, it was also recorded that, Karanja is most under utilized by the farming community even the plant which is grown abundantly in various parts of Tumkur district. It is reported that pongamia is non-edible oil which contains several toxic and unsaponifiable components. The presence of these multifarious compositions makes the oil unsuitable for human consumption. As pongamia has high oil content ( 40\%) and can grow on malnourished soils with low levels of nitrogen and high levels of salt, it is prompt in becoming the focus of a number of biodiesel research programs. Generally, the oil is contaminated with high free fatty acids depending upon the moisture content in the seed during collection as well as oil expression.

In the absence of biodiesel production facilities, farmers are selling these seeds in the market to a paltry amount of rupees 8-10 per $\mathrm{kg}$, most of which goes towards the cost of gathering and decortications of seeds from pods. As a result, they are resorting to cut these trees for firewood. Therefore, there is a need to retain these perennial trees by motivating the farmers in production of biodiesel for captive use and to fetch value addition to the produce. This is possible only on supply of appropriate equipment at village level for biodiesel production [9-13].

In current scenario, the promotion of biodiesel through novel strategies can meet the annual requirement of petro-fuel in India. It is astounding that nearly five tonnes of non-edible oil seeds can generate more than two tonnes of biodiesel which can facilitate the automobile industries most effectively. In addition, the engendered biproducts can promote the pattern of agro-industries towards sustainable agriculture production.

No considerable inputs are required to rise the pongamia (karanj) via plantation and the rational production of seeds can be achieved in the cropping period of three months even in deprived and tarnished or imperfect soil types. Genetically, pongamia is a highly resistant tree which comprises pest and disease resistant traits in its tissue system which can give first yield in 3 to 5 years after plantation. Surprisingly, pongamia tree will not be grazed by any animals thus; the generation of seeds are estimated from 6 to 12 tonnes per hectare per year in different soil types under varied rainfall conditions.
At present, an approach has been proposed to produce seeds at optimal level where nearly $45 \%$ of the yield can be transformed into esterified oil via transesterification process called biodiesel. After 5th year of pongamia plantation, an estimated yield of 0.75 to 2 tonnes of biodiesel can be achieved per year. The biodiesel produced from any other type of seeds like, rape seed, mahua, jatropha, etc. are analytically justified as similar to each other thus; the biodiesel produced by varied seed types can be recommended for automobile industries without attempting any modifications in the existing engine system.

Besides, the supply of biodiesel production equipment, it is also required to supply decorticator machines for de-shelling of pongamia pods to separate seeds which will reduce drudgery of rural women.

\section{EXPERIMENTAL}

The objectives of the proposed study were implemented at Department of Engineering Chemistry, Maharaja Institute of Technology, Thandavapura, India. The extensive literatures were studied to develop different protocols for the execution of Experiments at University Department of Chemistry, Ranchi University, Ranchi, India.

Collection of pongamia seeds: The baseline survey was conducted at the selected taluks of Tumkuru district (Karnataka state) and the interaction was made with lead farmers in order to gather first hand information's about cultivation, seed collections, manual decortications, physio-morphological properties of Pongamia sps. (local cultivar and geographically different type). Later on, the seeds of Pongamia sps. were collected directly from village farmers followed by seed nodal centres, Tumkur district, Karnataka (India). The seeds were segregated according to their shape and size during de-shelling of pongamia pods with the help of decorticator (seed separator). Further, the seeds were subjected for sun drying for 4-5 days till the seeds are attained complete drying. The seeds $(1 \mathrm{~kg})$ were then subjected for oil extraction using suitable oil expeller.

Extraction of oil from pongamia seeds: The oil was extracted using expeller prototype (single chamber oil expeller) by mechanical compress extraction approach and the yield of oil was recorded. This process requires no extra time and recovers oil completely (95\%) in higher proportions as compared to other methods reported in the previous studies.

Transesterification process for production of biodiesel: The process involved in transesterification is the reaction of triglyceride (fat/oil) with an alcohol in the presence of acidic, alkaline or lipase as a catalyst to form mono alkyl ester i.e., biodiesel and the by-product is glycerol. However, the presence of strong acid or base accelerates the conversion of oil into esterified oil during the transesterification [14].

In the present study, the oil of Pongamia sps. was subjected for transesterification using methyl alcohol in presence of strong alkaline catalyst in a batch type transesterification reactor. This reaction further facilitates to reduce the high viscosity of triglycerides.

Procedure: The crude oil of pongamia was taken and sodium hydroxide was added to methyl alcohol, which forms sodium methoxide, simultaneously oil was heated in a separate vessel of tranesterifaction reactor and subjected to heating and 
stirring. When the temperature of oil reached at $60^{\circ} \mathrm{C}$ then, sodium methoxide was mixed into the oil and reaction mixture was subjected for stirring for about $90 \mathrm{~min}$. After the completion of reaction, the reaction mixture was transferred into a separating funnel. The mixture was allowed to settle for 4-6 h, then glycerol and methyl esters were separated manually. Then, methyl ester was subjected for washing with hot water in order to remove traces of sodium hydroxide impurity if any [15]. Further, the washed methyl ester is the biodiesel and then subjected for distillation to remove moisture and good quality biodiesel was finally subjected for physico-chemical analysis [16].

\section{RESULTS AND DISCUSSION}

In the present study, the statistics of pongamia cultivation with respect square area was recorded $[9,11]$. The oil extracted from pongamia seeds was optimum and its physico-chemical properties confirms its ostentatious nature. Therefore, the pongamia was instituted naturally followed by village farmers based on its remarkable utilization which is now considered as an untapped resource for the biofuels industry of the future and to demand for transport fuel that is increasing unabatedly in India $[12,13,14]$.

Characterization of pongamia seed: The seeds were obtained through manual decortications and subjected for physio-morphological studies. The seeds in the lot was observed thoroughly and the outline structure was found to be largely similar to bean or kidney shaped with respect to configuration. Further, the seeds were subjected for interior compositions i.e., moisture content @ 10-12 \% from fresh seed and oil content: $35-38 \%$ which is dried.

Extraction and physico-chemical properties of oil: The pongamia seeds were subjected oil extraction using a suitable prototype and the percent yield of oil was calculated (Tables 1 and 2). The freshly extracted crude oil was found visually, yellowish red/ reddish brown and it was little darkened during the period of storage. The oil with respect to stink (pong) found to be having disagreeable odour followed by bitter taste. The extraction of oil from the seeds with suitable expeller gives good quality oil than other approaches with respect to extraction. The physico-chemical characteristic analysis was carried out as per the ASTM methods.

TABLE-1

OIL EXTRACTION BASED ON TIME CONSUMPTION

\begin{tabular}{cccc}
\hline $\begin{array}{c}\text { Amount of } \\
\text { seed taken }(\mathrm{g})\end{array}$ & $\begin{array}{c}\text { Time taken for oil } \\
\text { extraction }(\mathrm{min})\end{array}$ & $\begin{array}{c}\text { Oil } \\
\text { obtained }(\mathrm{g})\end{array}$ & $\begin{array}{c}\text { Cake } \\
\text { obtained }(\mathrm{g})\end{array}$ \\
\hline 500 & 34 & 145 & 320 \\
1000 & 70 & 315 & 650 \\
5000 & 372 & 1604 & 3180 \\
\hline
\end{tabular}

Analysis of fatty acid composition in pongamia oil: In pongamia oil, the available fatty acids were qualitatively analyzed in terms of percentage (Table-3).

Characteristic features of methyl ester derived from pongamia oil: Studies were carried out to standardize various parameters such as different ratio of sodium hydroxide, oil ratio and duration of the reaction. The different concentrations of methanol and sodium hydroxide were used at different duration.

\begin{tabular}{ll}
\multicolumn{1}{c}{ TABLE-2 } \\
\multicolumn{1}{c}{$\begin{array}{c}\text { PHYSICO-CHEMICAL CHARACTERISTICS } \\
\text { DATA IN CRUDE OIL OF Pongamia sps. }\end{array}$} \\
\hline \multicolumn{1}{c}{ Parameters } & \multicolumn{1}{c}{ Observation/Value } \\
\hline Colour & Pale brownish \& red \\
Odour & Characteristic odd odour \\
Density $(\mathrm{gm} / \mathrm{cc})$ & 0.924 \\
Viscosity $\left(\mathrm{mm}^{2} / \mathrm{s}\right)$ & 40.2 \\
Acid value $(\mathrm{mg} / \mathrm{KOH})$ & 5.40 \\
Iodine value & 87 \\
Saponification value & 184 \\
Calorific value $(\mathrm{kcal} / \mathrm{kg})$ & 8742 \\
Specific gravity & 0.925 \\
Flash point $\left({ }^{\circ} \mathrm{C}\right)$ & 225 \\
Fire point $\left({ }^{\circ} \mathrm{C}\right)$ & 230 \\
Cloud point $\left({ }^{\circ} \mathrm{C}\right)$ & 3.5 \\
Pour point $\left({ }^{\circ} \mathrm{C}\right)$ & -3 \\
Boiling point $\left({ }^{\circ} \mathrm{C}\right)$ & 316 \\
Cetane number & 42 \\
Copper-strip corrosion & No corrosion observed \\
Ash point $(\%)$ & 0.07 \\
\hline
\end{tabular}

TABLE-3

FATTY ACID COMPOSITION IN CRUDE OIL of Pongamia sps.

\begin{tabular}{lcrl}
\hline $\begin{array}{c}\text { Fatty acid } \\
\text { composition } \\
\text { in Pongamia } \\
\text { oil }\end{array}$ & m.f. & $\begin{array}{r}\text { Fatty } \\
\text { acid } \\
(\%)\end{array}$ & \multicolumn{1}{c}{ Structure of fatty acids } \\
\hline Palmitic acid & $\mathrm{C}_{16} \mathrm{H}_{32} \mathrm{O}_{2}$ & 12.42 & $\mathrm{CH}_{3}\left(\mathrm{CH}_{2}\right)_{14} \mathrm{COOH}$ \\
Stearic acid & $\mathrm{C}_{18} \mathrm{H}_{36} \mathrm{O}_{2}$ & 7.76 & $\mathrm{CH}_{3}\left(\mathrm{CH}_{2}\right)_{16} \mathrm{COOH}$ \\
$\begin{array}{l}\text { Oleic acid } \\
\text { Linoleic acid }\end{array}$ & $\mathrm{C}_{18} \mathrm{H}_{34} \mathrm{O}_{2}$ & 50.88 & $\mathrm{CH}_{3}\left(\mathrm{CH}_{2}\right)_{14}(\mathrm{CH}=\mathrm{CH}) \mathrm{COOH}$ \\
$\begin{array}{l}\text { Eicosanoic } \\
\text { acid }\end{array}$ & $\mathrm{C}_{20} \mathrm{H}_{40} \mathrm{O}_{2}$ & 16.75 & $\mathrm{CH}_{3}\left(\mathrm{CH}_{2}\right)_{12}(\mathrm{CH}=\mathrm{CH})_{2} \mathrm{COOH}$ \\
$\begin{array}{l}\text { Dosocasnoic } \\
\text { acid }\end{array}$ & $\mathrm{C}_{22} \mathrm{H}_{44} \mathrm{O}_{2}$ & 5.10 & $\mathrm{CH}_{3}\left(\mathrm{CH}_{2}\right)_{18} \mathrm{COOH}$ \\
$\begin{array}{l}\text { Tetracosanoic } \\
\text { acid }\end{array}$ & $\mathrm{C}_{24} \mathrm{H}_{48} \mathrm{O}_{2}$ & 1.32 & $\left.\mathrm{CH}_{2}\right)_{20} \mathrm{COOH}\left(\mathrm{CH}_{2}\right)_{22} \mathrm{COOH}$ \\
\hline
\end{tabular}

The highest recovery of biodiesel was $86 \%$ at $10 \%$ of methanol and $0.05 \%$ of sodium hydroxide with time duration of $1 \mathrm{~h}$. The observation made on the esterified oil of pongamia (biodiesel) was found to be almost similar to that of petroleum diesel which is substantiated during comparative analysis. The overall approach with respect to methyl ester derived from pongamia oil showed good properties (Table-4).

In addition, the value added substances like cake generated during oil extraction followed by glycerine generated through transesterification was also measured with respect to total recovery of biodiesel (Table-5). Further, methyl ester properties obtained from the oil of Pongamia sps. were compared with ASTM approach. This is most promising that the esterified oil was found to be approximately similar to that of petroleum diesel (Table-6).

\section{Conclusion}

Pongamia oil may stands as biodiesel which is renewable, safe and non-polluting and it holds great promise to the rural sectors of India to meet the energy and organic fertilizer requirements. Indeed further research is to be carried out on Pongamia to standardize agro-technology, low cost and efficient mechanical device to expel oil, to find out the economics, high yielding and high oil content varieties suitable to the different agro- 
TABLE-4

ESTERIFICATION BASED ON ORDER OF ADDITION OF REACTANTS

\begin{tabular}{|c|c|c|c|c|c|}
\hline Pongamia oil $(\mathrm{mL})$ & Methanol (\%) & $\mathrm{NaOH}(\%)$ & Order of addition & Time (min) & Biodiesel (\%) \\
\hline 20 & 20 & 0.1 & $\mathrm{Oil}+\mathrm{NaOH}+$ methanol & 60 & 25.0 \\
\hline 20 & 20 & 0.1 & $\mathrm{Oil}+\mathrm{NaOH}+$ heat + methanol & 60 & 22.5 \\
\hline 20 & 20 & 0.1 & $\mathrm{Oil}+\mathrm{NaOH}+$ heat + methanol & 60 & 25.0 \\
\hline 50 & 20 & 0.2 & $\mathrm{Oil}+\mathrm{NaOH}+$ heat + methanol & 60 & 20.0 \\
\hline 50 & 30 & 0.5 & $\mathrm{Oil}+\mathrm{NaOH}+$ heat + methanol & 60 & 10.0 \\
\hline 50 & 40 & 0.1 & $\mathrm{Oil}+\mathrm{NaOH}+$ heat + methanol & 60 & 28.0 \\
\hline 100 & 40 & 2.0 & $\mathrm{NaOH}+$ methanol + oil + heat & 60 & Nil \\
\hline 100 & 40 & 1.0 & $\mathrm{NaOH}+$ methanol + oil + heat & 60 & Nil \\
\hline 100 & 30 & 0.1 & Oil + heat $+($ mixed $\mathrm{NaOH}+$ methanol $)$ & 120 & 18.0 \\
\hline 100 & 30 & 0.2 & Oil + heat $+($ mixed $\mathrm{NaOH}+$ methanol $)$ & 120 & 15.0 \\
\hline 100 & 30 & 0.5 & Oil + heat $+($ mixed $\mathrm{NaOH}+$ methanol $)$ & 120 & 8.0 \\
\hline
\end{tabular}

\begin{tabular}{ccccc}
\multicolumn{5}{c}{ TABLE-5 } \\
$\begin{array}{cccc}\text { EFFECT OF DIFFERENT CONCENTRATIONS OF } \\
\text { CATALYSTS AND ORGANIC SOLVENTS ON ESTERIFICATION }\end{array}$ \\
\hline $\begin{array}{c}\text { Pongamia seed } \\
\text { oil }(\mathrm{mL})\end{array}$ & $\begin{array}{c}\text { Methanol } \\
(\%)\end{array}$ & $\begin{array}{c}\text { NaOH } \\
(\%)\end{array}$ & $\begin{array}{c}\text { Time } \\
(\mathrm{min})\end{array}$ & $\begin{array}{c}\text { Recovery of } \\
\text { biodiesel }(\%)\end{array}$ \\
\hline 50 & 30 & 0.100 & 240 & 75 \\
50 & 30 & 0.075 & 240 & 83 \\
50 & 30 & 0.100 & 180 & 74 \\
50 & 30 & 0.075 & 180 & 83 \\
50 & 15 & 0.050 & 120 & 82 \\
50 & 10 & 0.050 & 120 & 82 \\
50 & 15 & 0.050 & 60 & 78 \\
50 & 10 & 0.050 & 60 & 86 \\
\hline
\end{tabular}

\begin{tabular}{lccc}
\multicolumn{5}{c}{ TABLE-6 } \\
\multicolumn{4}{c}{$\begin{array}{c}\text { PROPERTIES IN METHYL ESTER OBTAINED FROM THE OIL } \\
\text { OF Pongamia sps. COMPARED WITH ASTM APPROACH }\end{array}$} \\
\hline \multicolumn{1}{c}{ Parameters } & $\begin{array}{c}\text { ASTM } \\
\text { approach }\end{array}$ & $\begin{array}{c}\text { Pongamia } \\
\text { biodiesel }\end{array}$ & $\begin{array}{c}\text { Petroleum } \\
\text { diesel }\end{array}$ \\
\hline Density (gm/cc) & D1482 & 0.888 & 0.854 \\
Calorific value (Kcal/Kg) & D268/D4855 & 3840 & 4321 \\
Cetane value (Number) & D642 & 46.2 & 48.8 \\
Acid value (mg/KOH) & D658 & 0.44 & 0.39 \\
Iodine value (Number) & D1565 & 96.2 & - \\
$\begin{array}{l}\text { Water and sediments } \\
\text { (\% vol, max.) }\end{array}$ & D2802 & 0.005 & - \\
\hline
\end{tabular}

climates of India [18-22]. The addition of variable reactants in the transesterification showed significant recovery of biodiesel at a specific temperature indicates the appropriateness in the protocol for achieving the optimum production of biodiesel [20,21,23,24]. In addition, Pongamia sps. has no challenging food uses thereby the plantation of pongamia has been promoted as most promising biodiesel tree based on its potential to grow in both tropical and subtropical climates across the world.

\section{ACKNOWLEDGEMENTS}

The authors express their sincere gratitude to Maharaja Institute of Technology, Thandavapura, Visvesvaraya Technological University, Belagavi and Department of Chemistry, Ranchi University, Ranchi, India for their laboratory, protocols, field support and literature, respectively.

\section{REFERENCES}

1. D. Huang, H. Zhou and L. Lin, Energy Procedia, 16, 1874 (2012); https://doi.org/10.1016/j.egypro.2012.01.287.
2. S. Jain and M.P. Sharma, Renew. Sustain. Energy Rev., 14, 763 (2010); https://doi.org/10.1016/j.rser.2009.10.005.

3. M.K. Senthil, A. Ramesh and B. Nagalingam, J. Institute Energy, 74, 24 (2001).

4. G. Dwivedi, S. Jain and M.P. Sharma, Smart Grid Renew. Energy, 02, 184 (2011); https://doi.org/10.4236/sgre.2011.23022.

5. V.V. Prajapati, S. Ratnesh, M.T. Patel and G. Radhashyam, Int. J. Adv. Mechan. Eng., 7, 15 (2017).

6. S.K. Karmee and A. Chadha, Bioresour. Technol., 96, 1425 (2005); https://doi.org/10.1016/j.biortech.2004.12.011.

7. P. Gogoi, Pongamia Oil-A Promising Source of Bio-Diesel, Assam University Press, Assam, India (2008).

8. N. Mukta and Y. Sreevalli, Ind. Crops Prod., 31, 1 (2010); https://doi.org/10.1016/j.indcrop.2009.09.004.

9. S. Sangwan, D.V. Rao and R.A. Sharma, Nat. Sci., 8, 1 (2010).

10. S.P. Wani and T.K. Sreedevi, Pongamia's Journey from Forest to MicroEnterprise for Improving Livelihoods, Andhra University Press, Andhra Pradesh, India (1999).

11. P.T. Scott, L. Pregelj, N. Chen, J.S. Hadler, M.J. Djordjevic and P.M. Gresshoff, BioEnergy Res., 1, 2 (2008); https://doi.org/10.1007/s12155-008-9003-0.

12. V. Kesari, A. Das and L. Rangan, Biomass Bioenergy, 34, 108 (2010); https://doi.org/10.1016/j.biombioe.2009.10.006.

13. A.K. Agarwal, TERI Inform. Digest Energy, 83, 191 (1998).

14. A. Demirbas, Energy Convers. Manage., 43, 2349 (2002); https://doi.org/10.1016/S0196-8904(01)00170-4.

15. L.C. Meher, V.S.S. Dharmagadda and S.N. Naik, Bioresour. Technol., 97, 1392 (2006); https://doi.org/10.1016/j.biortech.2005.07.003.

16. A. Demirbas, Energy Convers. Manage., 49, 125 (2008); https://doi.org/10.1016/j.enconman.2007.05.002.

17. M. Mohibbeazam, A. Waris and N. Nahar, Biomass Bioenergy, 29, 293 (2005); https://doi.org/10.1016/j.biombioe.2005.05.001.

18. V. Lakshmikanthan, Tree Borne Oil Seeds, Directorate of Non-edible Oils and Soap Industry, Khadi and Village Industries Commission, Mumbai, India, p. 10 (1978).

19. F. Ma and M.A. Hanna, Bioresour. Technol., 70, 1 (1999); https://doi.org/10.1016/S0960-8524(99)00025-5.

20. L.C. Mehar, S.N. Naik and L.M. Das, J. Sci. Ind. Res. (India), 63, 193 (2004).

21. M. Atapour and H.-R. Kariminia, Appl. Energy, 88, 2377 (2011); https://doi.org/10.1016/j.apenergy.2011.01.014.

22. A.N. Phan and T.M. Phan, Fuel, 87, 3490 (2008); https://doi.org/10.1016/j.fuel.2008.07.008.

23. H. Raheman and A.G. Phadatare, Bioenergy News, 7, 17 (2003).

24. H. Venkatesh Kamath, I. Regupathi and M.B. Saidutta, Fuel Process. Technol., 92, 100 (2011); https://doi.org/10.1016/j.fuproc.2010.09.003. 